\title{
EUGENIC POLICIES IN ALBERTA: FROM THE SYSTEMATIC TO THE SYSTEMIC?
}

\section{TIMOTHY CAULFIELD and GERALD ROBERTSON ${ }^{\circ}$}

Eugenics - derived from Greek meaning "well born" - has had a long histony in Alberta. It began in 1928 with the first Sexual Sterilization Act which permitted a Board to authorize sexual sterilization of those discharged from mental institutions. Further amendments to the Act expanded criteria to allow sterilization without consent in certain circumstances. The Act in all of its forms was influenced by the eugenics movement and U.S. legislation, which in turn was based on questionable social and scientific assumptions. Most prominent in eugenics thinking was the idea that mental illness, criminal and immoral behaviour were heredilary. As these traits were considered a financial and social burden on the state, it was believed to be in society's interest to eliminate these traits via sexual sterilization.

However, though the Act was repealed in 1972, there is a danger of a new eugenics emerging. With advances in genetic testing and research, individuals -- without state coercion - can make choices about reproduction through genetic services which can identify what may be considered genetic defects in fetuses. Even more, there is a strong element of autonomy in the law which reinforces personal choice. Thus, it is of the utmost importance that genetic equality, tolerance and broad view of normalcy, with a respect for an individual's health care decision, be promoted to avoid potential pitfalls of a new eugenics.
L'eugénique - du grec eu, bien, et genos, race a une longue histoire en Alberta. Elle voit le jour en 1928, avec l'adoption de la première loi sur la stérilisation sexuelle des attardés et des malades mentaux [The Sexual Sterilization Act]. La loi fait l'objet de modifications autorisant la stérilisation sans l'accord des intéressés dans certaines circonstances. La loi albertaine reflète à tous égards le mouvement eugénique et les lois en vigueur aux États-Unis, qui se fondent sur des hypothèses sociales et scientifiques douteuses soutenant essentiellement que les maladies mentales, les comportements criminels et immoraux seraient héréditaires. Compte tenu du fardeau financier et social qu'ils constituent pour l'État, on estime qu'il convient de les éliminer par la stérilisation sexuelle, dans l'intérêt de la société.

Bien que cette loi ait été abolie en 1972, un nouveau mouvement eugénique pourrait renaitre. Avec les progrès de la recherche et des tests génétiques, il est désormais possible de recourir $\dot{a}$ des services génétiques visant à dépister de prétendus défauts génétiques chez le foetus, sans aucune coercition de l'État. De plus, il existe en matière de droit un fort élément d'autonomie qui renforce le choix personnel. Ainsi, il est impératif de promouvoir l'égalité génétique, la tolérance et l'ouverture d'esprit en matière de normalité, compte tenu des prérogatives individuelles en matière de santé, afin d'éviter les dangers possibles d'un renouveau eugénique.

\section{TABLE OF CONTENTS}

I. INTRODUCTION $\ldots \ldots \ldots \ldots \ldots \ldots \ldots \ldots \ldots \ldots 60 \ldots$

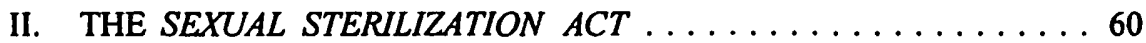

A. BACKGROUND TO THE $A C T \ldots \ldots \ldots \ldots \ldots \ldots$

B. THE INFLUENCE OF EUGENICS ON THE $A C T \ldots \ldots \ldots 62$

C. THE PHILOSOPHY OF THE

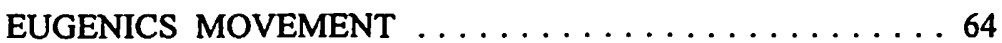

D. THE SOCIAL CLIMATE OF THE

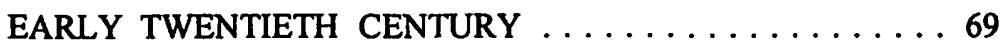

III. THE NEW EUGENICS $\ldots \ldots \ldots \ldots \ldots \ldots \ldots \ldots \ldots$

A. INTRODUCTION $\ldots \ldots \ldots \ldots \ldots \ldots \ldots \ldots \ldots \ldots$

Timothy Caulfield is an Assistant Professor of Law, and Research Director, Health Law Institute, University of Alberta. Gerald Robertson is a Professor of Law, University of Alberta. 


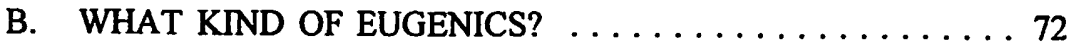

C. EUGENICS AND PERSONAL CHOICE $\ldots \ldots \ldots \ldots \ldots 73$

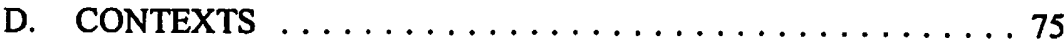

E. GUARDING AGAINST A NEW EUGENICS ........ 78

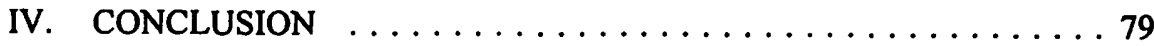

\section{INTRODUCTION}

In keeping with the "then and now" theme of this issue of the Alberta Law Review, this article explores the subject of eugenics in Alberta, as it existed seventy-five years or so ago, and as it exists today. The focus of the first part of the article is Alberta's Sexual Sterilization Act, ${ }^{\prime}$ and the eugenic and social forces which influenced its enactment in 1928 and its sustained use during the next forty-four years. The Act has received considerable media attention over the past year, ${ }^{2}$ particularly as a result of the recent judgment in Muir v. Alberta, ${ }^{3}$ in which damages of approximately $\$ 750,000$ were awarded to a woman who was wrongfully sterilized under the Act in 1959.

The second part of the article discusses what is often referred to as the "new eugenics," namely, the possibility that advances in human genetics and technology will rekindle attitudes strongly reminiscent of the eugenic philosophy which was so prevalent in the 1920s and 30s in North America in general, and Alberta in particular.

\section{THE SEXUAL STERILIZATION $A C T^{4}$}

\section{A. BACKGROUND TO THE ACT}

The Sexual Sterilization Act ("the Act") was passed in 1928 and revised in 1937 and again in 1942..$^{5}$ It established a board comprised of four individuals appointed by the Lieutenant Governor in Council, widely referred to as the "Eugenics Board." In its original form the Act empowered the Board to authorize the sexual sterilization of individuals about to be discharged from a mental hospital, if the Board was satisfied that "the patient might safely be discharged if the danger of procreation with its attendant risk of multiplication of the evil by transmission of the disability to progeny

\section{S.A. 1928 , c. 37.}

See e.g. D. Thomas, "Eugenics had Powerful Backers" Edmonton Journal (24 June 1995) B1. (1996), 132 D.L.R. (4th) 695 (Alta. Q.B.) [hereinafter Muir].

This section of the article is based on an expert report prepared by one of the authors on behalf of the Plaintiff in Muir. The report appears in its entirety as an appendix to the judgment in Muir, ibid. at 744-59.

5 For a general description of the provisions of the Act see Alberta Institute of Law Research and Reform, Sterilization Decisions: Minors and Mentally Incompetent Adults (Report for Discussion No. 6) (Edmonton: Institute of Law Research and Reform, 1988); W.F. Bowker, "Minors and Mental Incompetents: Consent to Experimentation, Gifts of Tissue and Sterilization" (1981) 26 McGill L.J. 951; B. Dickens, "Eugenic Recognition in Canadian Law" (1975) 13 Osgoode Hall L.J. 547; Law Reform Commission of Canada, Sterilization: Implications for Mentally Retarded and Mentally Ill Persons (Working Paper No. 24) (Ottawa: Minister of Supply and Services Canada, 1979); K. McWhirter \& J. Weijer, "The Alberta Sterilization Act: A Genetic Critique" (1969) 19 U.T.L.J. 424. 
were eliminated." Consent of the person (or of a spouse, parent or guardian, if the person was incapable of giving a valid consent) was required.

Following the 1937 amendments, ${ }^{6}$ the $A c t$ made specific reference to "psychotic" persons and "mentally defective" persons. The criteria for sterilization were expanded to include not only the risk of transmission of mental disease or disability, but also the risk of mental injury either to the individual or to his or her progeny. Consent of the individual (or if incapable, substitute consent) continued to be required, but only in the case of a psychotic person; for the sterilization of a mentally defective person, there was no statutory requirement of consent. The 1942 amendments $^{7}$ expanded the power of the Board to authorize sterilization, to include cases of neurosyphilis, epilepsy with psychosis or mental deterioration, and Huntington's Chorea. Consent was required in these cases, except for an individual with Huntington's Chorea who was also psychotic.

During the forty-four years in which the Act was in effect, the Board approved 4,725 cases for sterilization, of which 2,822 were actually performed. ${ }^{8}$ Many of these were children under the age of puberty. ${ }^{9}$ Furthermore, detailed studies of how the Act was administered have shown that its effects were highly discriminatory. The legislation had a disproportionate impact on females, the unemployed, people of minority ethnic backgrounds, and those in lower socio-economic groups. ${ }^{10}$

Though popular when first introduced, the Act eventually became the target of considerable criticism, on genetic, legal and moral grounds." "For example, it was described as "a disgrace to the whole of Canada,"12 and a "shameful blot on our past." ${ }^{13}$

The Act was finally repealed in $1972 .{ }^{14}$ In introducing the Bill which repealed the Act, its sponsor, Mr. King, cited three reasons for the government taking this step. The first was that the Act was based on medical and genetic theories which were now of questionable scientific validity. Second, the Act was riddled with legal ambiguities, so much so that the government had received a legal opinion which indicated that the protection from civil liability which s. 9 of the Act purported to confer on those who participated in a sterilization operation or decision was probably ineffective. Mr. King added that it was now the government's belief that "[s]ection 9 is legally

S.A. 1937 , c. 47.

S.A. 1942 , c. 48.

- A. McLaren, Our Own Master Race: Eugenics in Canada, 1885-1945 (Toronto: McClelland \& Stewart, 1990) at 159.

McWhirter \& Weijer, supra note 5.

to

T. Christian, The Mentally III and Human Rights in Alberta: A Study of the Alberta Sexual Sterilization Act (Edmonton: Faculty of Law, University of Alberta, 1974); Law Reform Commission of Canada, supra note 5.

" Bowker, supra note 5; Christian, ibid; Dickens, supra note 5; Law Reform Commission of Canada, supra note 5; McWhirter \& Weijer, supra note 5.

12 McWhirter \& Weijer, ibid. at 430.

13 Alberta Institute of Law Research and Reform, supra note 5 at 30.

$14 \quad$ S.A. 1972 , c. 87. 
indefensible."'15 Lastly, Mr. King cited human rights concerns as the strongest reason for repealing the legislation, describing the Act as embodying "a reprehensible and intolerable philosophy and program for this province and this government."16

\section{B. THE INFLUENCE OF EUGENICS ON THE $A C T$}

The evidence that the $A c t$ was motivated by eugenic considerations is overwhelming. Numerous authors have expressed the opinion that the Act was inspired by the philosophy of the eugenics movement. ${ }^{17}$ The influence of eugenic theories on the Act was recognized by the Supreme Court of Canada in Re Eve, ${ }^{18}$ and is also evident from the very fact that the Board established by the Act was widely referred to as the "Eugenics Board."

Newspaper reports of the debates on the $A c t$ as it passed through the legislative assembly leave no doubt as to its eugenic roots. The Bill was sponsored and introduced by the then Minister of Agriculture and Health for Alberta, the Honourable George Hoadley. During second reading of the Bill, Mr. Hoadley referred to the need for the state to be "protected from the menace which the propagation by the mentally diseased brings about."19 Likewise, during third reading of the Bill, Premier Brownlee is reported as stating that the Bill applied only to those who were a "menace to the community." ${ }^{20}$ During second reading, Mr. Hoadley stated that "[i]f it is quantity of production of the human race that is required, then we don't need this Bill, but if we want quality, then it is a different matter." 21

Further evidence of the influence of eugenic theory on the Act is provided by Pocock. ${ }^{22}$ She describes a meeting which she had with George Hoadley, three years after the $A c t$ was passed. Her discussions with the Minister provide a revealing insight into the eugenic motivation underlying the Act. She describes the meeting as follows:

I had the pleasure last year of meeting the Minister of Agriculture and Health, the Hon. George Hoadley, at his headquarters in Edmonton, and of hearing from him the history of the passing of the Bill.

$20 \quad$ "Sterlization Bill Finally Adopted in House" Edmonton Journal (7 March 1928) 5.

21 "Hoadley Sterlization Bill Occupies Attention of the Legislatures" Medicine Hat News (24 February 1928) 5.

22 H.F. Pocock, "Sterilization in the Empire: An Account of the Working of the Alberta Act" (1932) 24 Eugenics Review 127.

Reports of the Debates of the 17th Legislative Assembly of Alberta (31 May 1972) at 58-38.

Ibid. at 58-37.

Alberta Institute of Law Research and Reform, supra note 5; Bowker, supra note 5; T.L. Chapman, "Early Eugenics Movement in Western Canada" (1977) (Autumn) Alberta History 9; Christian, supra note 10; Dickens, supra note 5; Law Reform Commission of Canada, supra note 5; A. McLaren, supra note 8; McWhirter \& Weijer, supra note 5.

(1986), 31 D.L.R. (4th) 1 at 29 (S.C.C.).

"Lengthy Discussion Ensues in House on Sterilization Bill" Edmonton Journal (24 February 1928) Leng 
He himself is a farmer, and was struck, in the course of his business, with the importance of the laws of inheritance as applied to stock raising. Taking that application further to the human being, he came to the conclusion that in a new country, with a population of moderate size in healthy surroundings, some definite step should be taken to prevent the weakening of the race by the production of subnormal individuals. Just at this time (1925), the Royal Commission on Mental Hygiene was sitting in British Columbia, and the findings of their report impressed him so much that he came to the conclusion that their recommendation for the sterilization of certain aments [mental defectives] was one to be followed up. After a fairly stiff fight the Sexual Sterilization Act was passed by the Parliament in Edmonton and ratified by the Lieutenant Govemor in Council. ${ }^{23}$

Many prominent Albertans at that time were supporters of the eugenics movement, including Emily Murphy and Louise McKinney, who publicly expressed support for the Act $^{24}$ and Dr. R.C. Wallace, the then president of the University of Alberta, who gave an address in support of eugenics to the annual meeting of the Canadian Medical Association in Calgary in $1934 .{ }^{25}$ Likewise, when the National Council of Women passed a resolution in 1925 calling for the sterilization of mental defectives, the greatest support came from its members in Alberta and British Columbia. These included such prominent women as Nellie McClung and Emily Murphy, who were at the forefront of the campaign for eugenic sterilization in Alberta. ${ }^{26}$

In the years leading up to the introduction of the Sexual Sterilization Bill in 1927, there were repeated calls for this type of legislation from various politically powerful groups, such as the United Farmers of Alberta and the United Farm Women of Alberta, all citing eugenic justifications in support of this measure. ${ }^{27}$ The influence of these groups is evident when one bears in mind that it was the United Farmers of Alberta government that was in power at the time and which ultimately championed the Bill through the legislature.

The Alberta legislation coincided with the enactment of similar statutes in many parts of the United States, which themselves were heavily influenced by the eugenics movement. $^{28}$ Beginning with the state of Indiana in 1907, eugenic sterilization legislation was enacted in fifteen states by 1917 , and in thirty-one states by $1937 .{ }^{29}$ There are numerous references to the U.S. legislation during the debates on the Sexual Sterilization Bill in the Alberta legislative assembly, and it is evident from these debates that the U.S. legislation had a profound influence on the $A c t .{ }^{30}$

The impact of the eugenics movement can be seen in other types of legislation which promoted its objectives. This is particularly true of marriage laws which prohibited individuals suffering from mental illness and mental retardation from marrying. Several

Ibid. at 127.

"Sterlization Act has Much Backing" Edmonton Journal (9 March 1928) 7.

R.C. Wallace, "The Quality of the Human Stock" (1934) 31 C.M.A.J. 427.

Christian, supra note 10; McLaren, supra note 8.

Chapman, supra note 17; Christian, ibid; McLaren, ibid.

Bowker, supra note 5; McWhirter \& Weijer, supra note 5.

Law Reform Commission of Canada, supra note 5.

Edmonton Journal (24 February 1928) 7. 
writers have shown that this type of legislation in the United States has its roots in the eugenic movement of the late nineteenth and early twentieth centuries. ${ }^{31}$ The same connection between sterilization laws, marriage laws, and the eugenics movement is evident in Alberta and British Columbia. A provision prohibiting the issuance of a marriage license where one party was "an idiot, insane or mentally incompetent" was first introduced in Alberta in $1925,{ }^{32}$ only three years before the Sexual Sterilization Act. Likewise, a similar licensing prohibition was enacted in British Columbia in 1930, three years prior to that province's Sexual Sterilization Act. ${ }^{33}$ In essence the marriage prohibition and the sterilization legislation shared the same objective - to reduce procreation by the insane and the "mentally defective."

\section{THE PHILOSOPHY OF THE EUGENICS MOVEMENT}

The word "eugenics" is derived from the Greek word meaning "well born." It was first used in 1883 by Sir Francis Galton, who founded the eugenics movement in 1904. The movement focused on both positive and negative eugenics, though with greater emphasis on the latter. Positive eugenics included the encouragement of procreation by individuals and groups who were viewed as possessing desirable characteristics and genes, thereby improving and strengthening the overall gene pool of society. Negative eugenics involved discouraging and decreasing procreation by individuals and groups who were viewed as having inferior or undesirable characteristics and genes. The goal of negative eugenics was pursued by a number of different methods aimed at limiting the capacity and opportunity for procreation, including sexual sterilization, marriage prohibition, segregation, and institutionalization. ${ }^{34}$

At the heart of the eugenics movement lay certain social and scientific assumptions. One such assumption, based on the work of Mendel, was that certain characteristics and traits were thought to be hereditary. Another was that these characteristics and traits were believed to be socially undesirable. Hence it was in society's interests to reduce the spread of these undesirable traits by limiting the power of reproduction by those individuals and groups who possessed them. ${ }^{35}$

S.J. Brakel et al., The Mentally Disabled and the Law, 3d ed. (Chicago: American Bar Foundation, 1985); S.F. Haavik \& K.A. Menninger, Sexuality, Law and the Developmentally Disabled Person (Baltimore: P.H. Brookes Publishing, 1981); B. Linn \& L. Bowers, "The Historical Fallacies Behind Legal Prohibitions of Marriages Involving Mentally Retarded Persons - The Eternal Child Grows Up" (1978) 13 Gonzaga Law Rev. 625.

32 Solemnization of Marriage Act, S.A. 1925, c. 39, s. 29.

33 G.B. Robertson, Mental Disability and the Law in Canada, 2d ed. (Toronto: Carswell, 1994). The B.C. Sexual Sterilization Act was repealed in 1973: Alberta Institute of Law Research and Reform, supra note 5 at 30.

34 M.H. Haller, Eugenics: Hereditarian Attitudes in American Thought (New Jersey: Rutgers University Press, 1963); H.S. Jennings, "Eugenics" in E.R.A. Seligman, ed., Encyclopaedia of the Social Sciences, vol. 5 (New York: MacMillan, 1931) 617; J.H. Landman, Human Sterilization: The History of the Sexual Sterilization Movement (New York: MacMillan, 1932); Law Reform Commission of Canada, supra note 5; McLaren, supra note 8. 
Among the characteristics which many eugenists viewed as almost exclusively hereditary were mental retardation, mental illness, pauperism, criminality, and various other social defects including prostitution, sexual perversion and other types of immoral behaviour. ${ }^{36}$ Eugenists also believed that these groups had a higher reproductive rate than other people. ${ }^{37}$

One concern which was sometimes voiced was that families with "defective" offspring were a financial burden on the State, especially in times of economic hardship. ${ }^{38}$ However, the economic argument was seen by most eugenists as secondary to the primary concern of preventing the social delinquency and crime which they attributed to mental retardation and other inherited conditions. Thus, for example, Gosney and Popenoe, two leading proponents of eugenic sterilization in the United States in the early twentieth century, estimated that the "civilized world" spends about $\$ 5$ billion caring for mental defectives in public institutions, but they added that "[t]his cost is trivial compared with the heartaches, crime and horror that find their origin in these defectives." ${ }^{39}$

Many eugenists in the late nineteenth and early twentieth century accepted in its entirety the view that criminality per se was an inherited characteristic. ${ }^{40}$ Others believed that while probably not hereditary itself, criminality was highly prevalent among individuals who suffered from conditions that were considered to be hereditary, such as mental retardation and mental illness. Hence, eugenists believed that there was a strong and indisputable correlation between mental disability (particularly mental deficiency) and criminality, ${ }^{41}$ and many claimed that negative eugenics would lead to a rapid reduction in criminality and other delinquencies. ${ }^{42}$

One of the most dominant and recurrent themes of eugenics philosophy in the late nineteenth and early twentieth century was the emphasis on this link between mental retardation and criminality, and the consequent "menace" which mental deficiency

Alberta Institute of Law Research and Reform, supra note 5; American Neurological Association, Eugenical Sterilization, Report of the Committee for the Investigation of Eugenical Sterilization (New York: MacMillan, 1936); Law Reform Commission of Canada, ibid.; D.K. Pickens, Eugenics and the Progressives (Nashville: Vanderbilt University Press, 1968).

Alberta Institute of Law Research and Reform, ibid; American Neurological Association, ibid:;

E.S. Gosney \& P. Popenoe, Sterilization for Human Betterment (New York: MacMillan, 1929); A.M.C. Gullattee, "The Politics of Eugenics" in J. Robitscher, ed., Eugenic Sterilization (Springfield: Charles C. Thomas, 1973) 82; Jennings, supra note 34; Law Reform Commission of Canada, ibid.

Reports of the Debates of the 17th Legislative Assembly of Alberta (31 May 1972); Edmonton Journal (24 February 1928); Law Reform Commission of Canada, supra note 5. Gosney \& Popenoe, supra note 37 at viii.

The concept of inherited criminality dates back to the second half of the nineteenth century, to the writings of the Italian psychiatrist, Cesare Lombroso, and those of other criminal anthropologists such as Morel: see Dickens, supra note 5; Haller, supra note 34. This work had a major influence on eugenic philosophy in North America, and intensified the demand for sterilization laws, because the school of criminal anthropology purported to provide scientific proof that criminality was hereditary.

$4 \quad$ Haller, ibid.; Landman, supra note 34.

42 Jennings, supra note 34. 
posed to society. For example, in an influential book published in 1914 entitled FeebleMindedness: An Inquiry into its Nature and Consequences, Henry Goddard, a leading specialist in delinquency in the United States, emphasized the correlation between mental retardation and crime, noting that "the Moron ... is a menace to society and civilization ... he is responsible to a large degree for many, if not all of our social problems. ${ }^{143}$

These views were echoed in numerous other writings and pronouncements of the proponents of eugenics, and of eugenic sterilization in particular. ${ }^{44}$ The reference to mental defectives as a "menace to society" or a "menace to civilization" appears repeatedly throughout eugenic literature. ${ }^{45}$ In his leading work on the eugenics movement in North America, Professor Haller notes that from 1910 to 1920 the perception of the feebleminded as a menace to society became a "major force in American social thought." ${ }^{46}$ Professor Haller explains that:

\begin{abstract}
One factor that caused, or at least confirmed, a belief in a close relation between feeblemindedness and crime was the concept of the moral imbecile that developed in the $1880 \mathrm{~s}$. While most feebleminded persons were believed to have an underdeveloped intellectual faculty and, in most cases, an underdeveloped moral faculty, the moral imbecile had only his moral faculty underdeveloped. Many institutions for the feebleminded had a few moral imbeciles committed to them, youths who were incorrigible, violent, sometimes sexually promiscuous. In the institutions they constituted a disrupting influence on their more docile fellow inmates. But the presence of such incorrigible youths and a belief that most feebleminded persons were likely to have an underdeveloped moral faculty gave a sort of scientific explanation to the belief that the feebleminded were a menace. ${ }^{47}$
\end{abstract}

The link between feeblemindedness and crime, and the resulting "menace" to society, were reinforced by studies such as the one by Dugdale in 1875 (and by Estrabrook in 1915) of the Jukes family, and numerous others published during the same period. These studies, which had considerable influence in Canada, ${ }^{48}$ purported to show widespread criminality and moral degeneracy among families with mental deficiencies. $^{49}$

This sentiment was also very much alive and well in Canada in the early part of the twentieth century. For example, E.W. McBride, the Strathcona Professor of Zoology at McGill University in the early 1900 s and a leading proponent of eugenics in Canada, called for the weeding out of prostitutes, criminals and drunkards by means of sterilization. Similarly, the work of Carrie Derick, a professor of botany at McGill and

Quoted in Linn \& Bowers, supra note 31 at 627.

Gosney \& Popenoe, supra note 37; Landman, supra note 34; P. Popenoe \& R.H. Johnson, Applied Eugenics, rev. ed. (New York: MacMillan, 1933).

Canadian National Committee for Mental Hygiene, Mental Hygiene Survey of the Province of Alberta (publisher not stated, 1921) 1; Gosney \& Popenoe, ibid. at viii; Haller, supra note 34 at 95; Landman, ibid. at 35; Pickens, supra note 36 at 3.

Haller, ibid. at 95.

Ibid. at 203.

McLaren, supra note 8.

Haller, supra note 34; Pickens, supra note 36. 
a prominent Montreal feminist, purported to show a high degree of mental deficiency among criminals, which she concluded indicated the need for society to free itself of the "menacing shadow of the mental defective." ${ }^{\text {50 }}$ Michael Steele, a Canadian M.P., relied on the work of Henry Goddard in informing Parliament in 1917 that "probably fifty per cent of all criminals are mentally defective." ${ }^{31}$ Likewise, in 1930 the Report of the (Ontario) Royal Commission on Public Welfare recommended the enactment of sterilization legislation to deal with immoral defectives and criminals. ${ }^{52}$

The same themes are evident in the work of Dr. Helen MacMurchy, a medical doctor and a government inspector of the feebleminded in Ontario from 1906 to 1916. Professor McLaren describes MacMurchy as the "best-known Canadian defender of the argument that sterilization was better than segregation as a way of dealing with the menace of feeble-mindedness...." ${ }^{53}$ In one of her annual reports, MacMurchy concluded that mental defectives were responsible for up to 60 percent of society's alcoholics, 66 percent of its juvenile delinquents, 50 percent of its unmarried mothers, and possibly 97 percent of its prostitutes. She expressly endorsed the view originally coined by Henry Goddard, that "every mental defective is a potential criminal." ${ }^{\text {"4 }}$ This was also a favourite phrase of Emily Murphy in the many speeches which she gave throughout Alberta in the 1920's, espousing the benefits of eugenic sterilization. ${ }^{55}$

Likewise, in his book entitled Constructive Eugenics and Rational Marriage, published in Toronto in 1934, Dr. Morris Siegel, a medical doctor practising in Hamilton, Ontario, writes as follows:

It is the moron, that gives society all the trouble and concern. They do propagate and their crops are quite large. They multiply at least as twice as fast as the normal. The male morons can never get along. They shift from job to job. Through recklessness and folly they manage all the time to get into trouble. It is chiefly they, that fill the jails, the hospitals and public institutions.

The female morons grow up to be irresponsible women, falling deeply into the abyss of prostitution, alcoholism, and addiction to narcotic drugs. The feeble-minded is responsible for more crime, degeneracy, and pauperism than any other single group....

Closely associated with the feeble-minded there is another large group commonly known as Defective delinquents. These are not always intellectually defective; on the contrary, they are sometimes unusually bright mentally, but they lack in the appreciation of moral sense. These are abnormally selfish, unstable, shrewd, dishonest, typical liars, utterly lack the power of inhibition or control of emotions, in many cases they are sexual perverts. It is these groups that make up the class which is usually known as habitual criminals....

McLaren, supra note 8 at 24.

Ibid. at 52.

Starkman, "The Control of Life: Unexamined Law and the Life Worth Living" (1973) 11 Osgoode

Hall L.J. 175.

33 McLaren, supra note 8 at 42.

s4 Ibid. at $\mathbf{4 0}$.

ss Christian, supra note 10. 
There are, however, about $60 \%$ of inmates [of jails and penitentiaries] who are Habitual Criminals. They are hardened crooks, cruel, ready to commit the most atrocious crimes on slight or no provocation. Most of those are mentally defective. They are either morons, epileptics, chronic alcoholics or defective delinquents. This group is absolutely unfit for parenthood. ${ }^{\text {s6 }}$

Dr. Siegel's text contains a foreword by the then Chancellor of McMaster University, describing the book as "well balanced" and "very enlightening. ${ }^{\text {"57 }}$

Attitudes such as these were not confined to the pages of academic texts or professional journals. They were widely disseminated in popular Canadian magazines and newspapers of the day. For example, Constance Templeton, in an article in Chatelaine in 1934, wrote of the "rapid increase" in the number of mentally defective people in Canada, with "many thousands" of them in jails and reformatories, where they "pile up police records of crime." ${ }^{58} \mathrm{Her}$ article also referred to the fact that Alberta and British Columbia had recently enacted sexual sterilization legislation in order to check this "alarming menace of national decadence." 59 Similar views appeared on numerous occasions in newspapers in Alberta and British Columbia in the 1920s and 1930s. ${ }^{60}$

In a similar vein, Maclean's Magazine published a speech in 1936 given by the Honourable H.A. Bruce, the then Lieutenant Governor of Ontario, in which he referred to the numbers of "imbeciles" in the population as "growing by leaps and bounds," and to the "alarming consequences if idiots are permitted to procreate their kind." He advocated sterilization as the only solution to the problem, and commended the Alberta government for its wisdom and courage in passing the $A c t .^{61}$

The emphasis of eugenics philosophy on preventing criminal behaviour is also apparent from the famous judgment of Mr. Justice Holmes in Buck v. Bell, ${ }^{62}$ a decision of the United States Supreme Court upholding the constitutional validity of the sterilization laws of Virginia. In the words of Justice Holmes:

It is better for all the world, if instead of waiting to execute degenerate offspring for crime, or to let them starve for their imbecility, society can prevent those who are manifestly unfit from continuing their kind. The principle that sustains compulsory vaccination is broad enough to cover cutting the Fallopian tubes.... Three generations of imbeciles are enough. ${ }^{63}$

M. Siegel, Constructive Eugenics and Rational Marriage (Toronto: McClelland \& Stewart, 1934) at 55-60.

Ibid. at v.

C. Templeton, "Canada's Lost Population" Chatelaine Magazine (1934) at 7:22.

lbid. Christian, supra note 10.

H.A. Bruce, "Sterilization and the Problems of the Mentally Unfit" Maclean's Magazine (1 July 1936) at 33.

274 U.S. 200 (1927).

Ibid. at 207. 
The Law Reform Commission of Canada described the decision in Buck v. Bell as having validated the "foundation of the eugenists' argument - the belief that mental illness, mental retardation and criminality are inherited."${ }^{164}$ Buck v. Bell unquestionably had an influence on the enactment of the sexual sterilization legislation in Alberta and British Columbia. ${ }^{65}$

\section{THE SOCIAL CLIMATE OF THE EARLY TWENTIETH CENTURY}

The social climate in the early twentieth century, both in the United States and in Canada, was especially receptive to eugenics philosophy, and in particular, to the image of the feebleminded as a menace to society. This was a period of great concern over a perceived surge in crime, prostitution, venereal disease, drug use and drunkenness, as well as growing labour unrest. ${ }^{66}$ The eugenics movement offered reassurance to the middle classes that social peace and harmony could be restored by implementing the tenets of applied eugenics. ${ }^{67}$ In addition, as Professor McLaren points out:

This fear of the feeble-minded was based on the assumption made by a large number of turn-of-thecentury commentators that mental deficiency was a cause of a host of social ills. For the middle class, of course, it was a comforting notion to think that poverty and criminality were best attributed to individual weakness rather than to the structural flaws of the economy. This explains why so many otherwise intelligent humanitarians supported the labelling, the segregation, and ultimately the sterilization of those they designated subnormal. ${ }^{68}$

At the same time, the claim was repeatedly made that mental deficiency was rapidly increasing in Canada and in Alberta. ${ }^{69}$ This message played a key role in creating an environment which was receptive to the image of the feebleminded as a menace to society.

Likewise, just as in the United States the eugenics philosophy exploited people's racist beliefs and fears, ${ }^{70}$ so too in early twentieth century Canada it flourished in a climate of growing suspicion and fear over the rising tide of immigrants to Canada, particularly from Eastern and Southern Europe and the Orient. ${ }^{11}$ Statements were repeatedly made by prominent Canadians that foreigners made up the majority of criminals in Canada, and that they posed a threat to the purity of the Anglo-Saxon race. Such sentiment was especially prevalent in Alberta. Professor McLaren notes that the fervour of the proponents of sexual sterilization was much more intense in Alberta than

Law Reform Commission of Canada, supra note 5 at 26.

Alberta Institute of Law Research and Reform, supra note 5.

Haller, supra note 34; Pickens, supra note 36; McLaren, supra note 8.

McLaren, ibid.

Ibid. at 37.

Canadian National Committee for Mental Hygiene, supra note 45; Christian, supra note 10; Edmonton Journal (16 February 1927) 1.

Haller, supra note 34; Pickens, supra note 36.

Chapman, supra note 17; Christian, supra note 10; McLaren, supra note 8. 
in British Columbia, and he attributes this to the higher percentage of immigration on the Prairies. ${ }^{72}$

This theme is also evident in the findings of the surveys conducted in the 1920's in various provinces (including Alberta) by the Canadian National Committee for Mental Hygiene ("CNCMH"). For example, the CNCMH reported in 1920 that its survey of Manitoba revealed that:

the feeble-minded, insane and psychopathic of that province were recruited out of all reasonable proportions from the immigrant class, and it was found that these individuals were playing a major role in such conditions as crime, juvenile delinquency, prostitution, pauperism, certain phases of industrial unrest, and primary school inefficiency. ${ }^{3}$

Similar findings were made in the CNCMH's survey of Alberta in $1921 .^{74}$ The CNCMH noted that "perhaps the chief menace of mental disability lies, not so much in the harm that the afflicted individuals bring upon themselves, but rather the ill-effects for which they are responsible upon their associates." ${ }^{75}$ It concluded that "in Alberta, as elsewhere, a considerable proportion of the chronic and flagrant offenders against the law are possessed of unsound mentality, and this latter factor is a contributing cause of the delinquency. ${ }^{176}$ The CNCMH painted a picture of alarming immorality and delinquency, which it attributed to mental deficiency, and it specifically singled out immigration as one of the causes of the problem.

In his comprehensive study of the Act, conducted in 1974, Tim Christian ${ }^{71}$ also demonstrates the close connection between the fear which many Albertans had of new immigrants and the ultimate passage of the Act. He states that:

In spite of the determined efforts of those who opposed the sexual sterilization proposal, the Government was able to impose a negative eugenics program in Alberta. The proponents of sexual sterilization had a powerful formula for garnering the support of many Albertans. Once the link between sexual immorality and mental deficiency had been formed in the public mind it was but a short step to introduce the notion that East European immigrants were the chief contributors to mental illness. The racial antipathy of the Anglo-Saxon majority toward Slavic immigrants provided a ready vehicle for popularizing the sterilization proposal. ${ }^{\text {r }}$

\section{A. INTRODUCTION}

\section{THE NEW EUGENICS}

The social policies which resulted in Alberta's sterilization laws were based, in part, on bad science. Simplistic and inaccurate views of human heredity dominated early

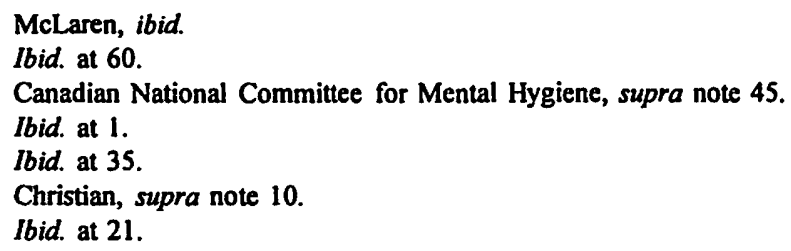


eugenic policy. ${ }^{79}$ If we could breed better farm animals why not better humans? ${ }^{80}$ Today, however, knowledge of human genetics has grown immensely - and is expanding at an unprecedented rate. While at the turn of the century we may have believed that criminality and laziness "ran in the family"81 today we can actually test individuals for many genetic disorders (e.g. cystic fibrosis, huntingtons disease, etc.), as well as for predispositions to many other multifactorial diseases such as breast cancer. In addition, there have been recent claims that a variety of complex behavioral characteristics have a strong genetic component (e.g. homosexuality and extrovertedness) ${ }^{82}$ As a result, one could argue that the tools of eugenics have never been sharper, nor more readily available. As one author has noted:

There is no question that eugenics has become a vastly more realizable prospect than it was in the earlier part of the century, and it must be granted that, in many ways, the very notion remains as disturbing as it was in $1945^{.3}$

To a large degree, many of the recent advances in human genetics are due to the international research initiative know as the Human Genome Project. This research undertaking - which has as its primary goal the mapping and sequencing of all the estimated 100,000 human genes - was commenced in 1990 as a joint project of the United States National Institutes of Health and the Department of Energy. Since then, other countries throughout the world have also launched official genome research programs. The Canadian initiative, a federal project entitled the Canadian Genome Analysis and Technology Program, first received funding in June of $1992 .{ }^{84}$

Is the fear that a "new eugenics" may emerge from this genetic revolution justified? Will the Human Genome Project herald in a new era of eugenic programs and policies? The answer, we would suggest, depends on the definition of eugenics one employs.

H. Friedlander, The Origins of Nazi Genocide: From Euthanasia to the Final Solution (Chapel Hill: The University of North Carolina Press, 1995) at 6 who notes that: "Viewed from our vantage point, eugenic research during the first half of the twentieth century was seriously flawed." See also R. Proctor, "Genomics and Eugenics: How Fair Is the Comparison?" in G. Annas \& S. Elias, eds., Gene Mapping: Using Law and Ethics as Guides (Oxford University Press: New York, 1992) at 60 , where the author notes that: "Traits as diverse as hernias, wanderlust, and divorce were assumed to be genetic."

For an interesting discussion of early eugenic programs, including "better baby" contests, see D. Nelkin \& M.S. Lindee, The DNA Mystique: The Gene as a Cultural Icon (New York: Freeman and Company, 1995), c. 2.

81

Ibid. at 26.

L. Thompson, "Search for a Gay Gene" Time (12 June 1995) 34; S. Strauss, "Progress Reported in Search for Gay Gene" The Globe and Mail (16 July 1993) Al; Associated Press, "Link Found Between Genetic Inheritance and Aggression" The Globe and Mail (22 October 1993); and N. Angier, "Trait of Extroverts Traced to Gene" The Globe and Mail (2 January 1996) Al.

E.F. Keller, "Nature, Nurture and the Human Genome Project" in D. Kevles \& L. Hood, The Code of Codes (Cambridge: Harvard University Press, 1992) at 299.

R. Worton, "CGAT - The First Year" (1993) 1 Genexpress 1 at 1. 


\section{B. WHAT KIND OF EUGENICS?}

The term "eugenics" has been used in a variety of ways. Eugenics as a "science" was described by its founder, Sir Francis Galton, as:

The study of aegis under social control that may improve or impair the racial qualities of future generations either physically or mentally. ${ }^{\text {ss }}$

Today, however, the term is more commonly used to describe not a branch of scientific study, but rather a type of social program which "involves efforts that interfere with individuals' reproductive choices in order to attain a 'societal' goal." ${ }^{86}$ Such "social control" definitions fit our current conception of eugenics as a mechanism used by repressive governments to achieve questionable social and political goals (such as the sterilization of the mentally handicapped). ${ }^{87}$

If one adopts this "social control" view of eugenics - that is, as referring to state implemented and organized programs designed to achieve a given social goal through coercive laws - then it seems doubtful that Canada will, at least in the foreseeable future, see the rise of that type of eugenics. ${ }^{88}$ Since the use of eugenic programs by Nazi Germany ${ }^{89}$ there has been a great deal of caution associated with the implementation of any state sponsored genetics initiative. Indeed, the wariness created by genetic's "eugenic past" is arguably a significant motivating force behind many of the almost universally accepted genetic safeguards, such as the restrictions on germ-line therapy and the need for non-directive genetic counselling. ${ }^{90}$

However, eugenic goals, such as the eradication of a given genetic disease, ${ }^{91}$ can be achieved by individuals making choices about reproduction and the use of genetic services. Some would argue, therefore, that it is not the formal "social control" programs which we should fear. Rather, we must consider how genetic services are

In F. Ledley, "Distinguishing Genetics and Eugenics on the Basis of Fairness" (1994) 20 Journal of Medical Ethics 157 at 158.

U.S. Congress, Office of Technological Assessment, Cystic Fibrosis and DNA Tests: Implications of Carrier Screening (Washington: U.S. Government, 1992) at 51.

As noted earlier, it is only in hindsight that eugenic laws seem so offensive. They were, one would presume, implemented with the best of intentions.

Not all countries have an aversion to state sponsored eugenic policies. See e.g. Reuter, "China to Pass Eugenics Law" The Globe and Mail (21 December 1993) Al, where it is reported that "China will use abortions and sterilizations to avoid new births of inferior quality and heighten the standards of the whole population."

Friedlander, supra note 79.

For a review of legal and ethical norms as they relate to human genetics see generally, Professional Norms in the Practice of Human Genetics (Special Edition) (1995) 3 Health Law Journal; B. Knoppers \& R. Chadwick, "The Human Genome Project: Under an International Ethical Microscope" (1994) 265 Science 2033; J. Gevers, "Responses of the Law to Developments in Genetics" (1995) 14 Medicine and Law 199; and M. Lupton, "Behaviour Modification by Genetic Intervention - the Law's Response" (1994) 13 Medicine and Law 417.

This was the state's goal of Nazi Germany's 1933 eugenic legislation entitled Law for the Prevention of Offspring with Hereditary Diseases: Friedlander, supra note 79 at 26. 
being utilized by individual patients and their health care providers. ${ }^{92}$ As noted by Roy, Williams and Dickens:

There is no need for a state-inspired and state-organized and, by implication, coercive eugenics programme, if voluntary parental uptake and utilization of prenatal diagnosis, with selective abortion of fetuses found to be defective, will, for all practical purposes, achieve the same result."3

Numerous factors will influence these individual choices concerning the use of genetic services, including social perceptions of the handicapped, disclosed health risks, market pressures, health care costs (both personal and social), perceived social obligations and conceptions of normalcy. ${ }^{94}$ It is in this combination of individual choice and perceptions, attitudes and beliefs where we may find a "new eugenics" emerge. If genetics becomes a mechanism whereby social prejudices and intolerance are reinforced and, indeed, allowed to shape future generations, then perhaps the fears of a "new eugenic" are justified. ${ }^{95}$

\section{EUGENICS AND PERSONAL CHOICE}

Few legal and ethical concepts are as dominant as the notion of autonomy. It is particularly important in the medical-legal setting as it forms the foundation of the doctrine of informed consent:

The concept of individual autonomy is fundamental to the common law and is the basis for the requirement that disclosure be made to a patient. $\%$

This was noted by J. Robertson, "The Potential Impact of the Human Genome Project on Procreative Liberty" in G. Annas \& S. Elias, eds., Gene Mapping: Using Law and Ethics as Guides (New York: Oxford University Press, 1992) at 218:

The product of many individual decisions by patients and physicians may thus lead to the widespread use of a test that could not be justified independently as a matter of social policy.

D. Roy, J. Williams \& B. Dickens, Bioethics in Canada (Scarborough: Prentice Hall, 1994) at 187.

See R. Mykitiuk \& S. Penney, "Screening for 'Deficits': The Legal and Ethical Implications of Genetic Screening and Testing to Reduce Health Care Budgets" (1995) 3 Health Law Journal 235 at 236; and also V. Burstyn, "Breeding Discontent" Saturday Night (June, 1993) 15 at 63:

The new reproductive technologies are being offered by individual doctors to individual women; there is no state or formal coersion. But the "private" decisions made by women and their doctors nevertheless reflect what kind of life is privileged and welcomed in the social and economic arrangements or our society - what kind of child is a "wanted" child.

J. Testart, "The New Eugenics and Medicalized Reproduction" (1995) 4 Cambridge Quarterly of Healthcare Ethics 304 at 305, cautions that:

[T]he new eugenics will be benevolent and learned, painless and efficient. These qualities make it a social means of regulating health and defining normality according to more and more restrictive conditions. 
Indeed, autonomy has been used as the basis for a variety of controversial legal decisions, such as: allowing a fifteen year old to refuse a life saving blood transfusion; ${ }^{97}$ affirming the right of a pregnant women to refuse a needed cesarian section; ${ }^{98}$ upholding the right of a hunger striker not to be force fed; 99 and the introduction of advanced directives legislation. ${ }^{100}$ Autonomy and the right to self determination have also been adopted by some factions of the health reform movement, arguably inaccurately, ${ }^{101}$ as a rationale for a right of access to health care - even if delivered through a private tier.

In the realm of genetics, the perceived paramountcy of autonomy has been highlighted by Wertz's research on the perceptions of genetic professionals. ${ }^{102}$ For example, Wertz found that 94 percent of genetic professionals in Canada thought that they had an obligation to refer a patient to another physician if they were unwilling to perform the procedure for moral reasons. ${ }^{103}$ Similarly, she found a surprising number of professionals who were willing to either refer or perform prenatal diagnosis for the purposes of sex selection (52-67 percent depending on the scenario). ${ }^{104}$ These findings demonstrate not an acceptance of sex selection, which Canadian health care professionals do not support and the Royal Commission on New Reproductive Technologies has suggested banning, ${ }^{105}$ rather, they highlight the tension between a perceived right of access and the professional's own moral views. ${ }^{106}$

The belief that the right of "patient choice" may trump other considerations seems to also be held by patients. Sixty-eight percent of patients surveyed by Wertz thought that withholding any requested service is paternalistic and 61 percent thought they were

Walker v. Region 2 Hospital Corp. (1994), 116 D.L.R. (4th) 477 (N.B.C.A.); Malette v. Shulman (1990), 67 D.L.R. (4th) 321 (Ont. C.A.).

Re Baby R. (1988), 53 D.L.R. (4th) 69 (B.C.S.C.), rev'g (1987), 9 R.F.L.(2d) 415 (Prov. Ct.). See also $\operatorname{Re} A$. (in utero) (1990), 75 O.R. (2d) 82 (Unified Fam. Ct.).

A.G.B.C. Stevenson and Merat v. Astaforoff and A.G. Can., [1984] 4 W.W.R. 385 (B.C.C.A).

A Joint Report of the Alberta Law Reform Institute and the Health Law Institute, Advance Directives and Substitute Decision-Making in Personal Healthcare, Report No. 64 (Edmonton: Alberta Law Reform Institute, 1993). Of course, autonomy was a dominant issue in the controversial decision of Rodriguez v. British Columbia (Attorney General), [1993] 3 S.C.R. 519. See R. Veatch, "Allocating Health Resources Ethically: New Roles for Administrators and Clinicians" (Fall 1991) 1 Frontiers of Health Services Management 3 at 12 where the author notes that autonomy "grants liberty rights, the right to decline or withdraw. It does not grant a right to access." See also T. Caulfield \& D. Ginn, "The High Price of Full Disclosure: Informed Consent and Cost Containment in Health Care" (1994) 22 Man. L.J. 328 at 338.

D. Wertz, "Professional Perspectives: A survey of Canadian Providers" (1995) 3 Health Law Journal 59.

Ibid. at 82.

lbid. at 83.

Royal Commission on New Reproductive Technologies, supra note 96.

This tension is further emphasized by the fact that she also found that 53 percent of genetic professionals thought they should refer a patient outside of Canada if domestic law forbids a requested genetic service: supra note 102 at 82 . 
entitled to any service they could pay for out of pocket. ${ }^{107}$ It is in this climate of patient choice and empowerment to which genetic services will be introduced.

\section{CONTEXTS}

Individual choices, even those as personal as reproductive decisions, will inevitably be influenced, constrained and shaped by the social context in which they are made. ${ }^{108}$ If the context is such as to promote eugenic goals, one could argue that the cumulative effect of the individual decisions, when made within these contexts, is eugenic. $^{109}$ The following is a brief review of three factors which may effect the contexts in which genetic services are provided.

\section{Commercial Interests}

Genetics is big business. One American author has estimated that the total DNA diagnostic market will be more than one billion dollars by $1998 .{ }^{110}$ Because of this potential for financial gain, to say nothing of the billions already invested in research and marketing, there exists clear motivation to ensure that genetic services are implemented and used." 1 As argued by Motulsky with respect to predictive testing:

The promise of a large and lucrative market for predictive testing of common diseases makes for strong pressures by commercial testing companies to offer such tests before they are thoroughly tested in the field. ${ }^{112}$

In order to promote such use, there must be a perceived need by both the health care community and the general public. This perceived "need" will relate, in part, to our views about such concepts as "normalcy." For example, as a society we are more likely to tolerate prenatal testing for "serious" disorders, ${ }^{113}$ therefore, the definition of "serious," and likewise "normalcy," becomes pivotal. The issue is then: will such

Ibid. While this patient survey was done on a relatively small sample size (ninety-nine), its results are supported by other research on American patients. For example, J. Fletcher \& D. Wertz, "Patients' ethical views on autonomy, new reproductive technology and prenatal diagnosis: a pilot study" (Poster presentation at the 44th Annual Meeting of the American Society of Human Genetics, Montreal, 21 October 1994) [abstract \#1712]:

Most [patients] thought withholding any service was a denial of patient rights (80\%), providers unwilling to do some procedures for moral reasons should offer referrals (79\%), prenatal tests should be available on request ( $75 \%)$, and consumers were entitled to whatever services they can pay for out of pocket $(61 \%)$.

For a discussion of the various factors which may affect the allocation of genetic services see $T$. Caulfield, "The Allocation of Genetic Services: Economics, Expectations, Ethics and the Law" (1995) 3 Health Law Journal 213.

109 Roy, Williams \& Dickens, supra note 93.

P. Silverman, "Commerce and Genetic Diagnosis" (1995) 25 Hastings Center Report S15 at S16. Royal Commission on New Reproductive Technologies, supra note 96 at 882. 
perceptions be influenced, even subtly, by commercial interests? At least some commentators fear the eugenic potential of commercial forces:

While contemporary eugenics may not be dictated from above by the political programmes of dictatorial regimes ... the pressures of the market are as forceful and destructive, if not more forceful and destructive, than what we have had in the past. 114

\section{Health Care Reform}

The new genetic technologies are emerging at a time of drastic health care reform. Cost control has become a paramount consideration in all health care allocation decisions. As a result, and despite commercial pressures to utilize genetic services, it seems inevitable that economic benefit will be one of the explicit rationales for the introduction of some genetic services. ${ }^{115}$ That is to say, genetic services may be justified on the basis of their ability to save the health care system money. ${ }^{116}$ Such an approach has obvious implications for both personal autonomy and the stigmatization of those newborns who may be perceived as having a "costly" genetic disability. ${ }^{117}$ Clarke cautions as follows:

If a [genetic] department's work is to be measured in such terms, there will be subtle - and possibly less than subtle - pressure upon clinicians to maximize the rate of terminations of pregnancy for "costly" disorders: a completely unacceptable outcome which we must strive to prevent. ${ }^{118}$

Quoted in Burstyn, supra note 94 at 63 . See also Testart, supra note 95 at 310 where it is argued that: "For reasons associated with the economy and the market, normality of human beings will be more and more defined according to the needs of industry and insurance contracts." The ever increasing presence of genetics in the popular media is also likely to encourage the use of genetic services and have a impact on our social conceptions of disease and normalcy. See generally Nelkin \& Lindee, supra note 80.

D. Wertz, "Ethical and Legal Implications of the New Genetics: Issues for Discussion" (1992) 35 Social Science Medicine 495.

116 For an example of cost containment being used as a rationale for the implementation of a mandatory, albeit non-genetic, screening program see T. Arnold, "HIV test urged for all pregnant women: Doctors want right to screen for virus" Edmonton Journal (5 March 1996) A7, where Dr. Guy Gokiert, president of the Alberta Medical Association, uses cost savings to justify the implementation of a mandatory HIV test: "By protecting one baby through testing you can probably do all the testing for a year in Alberta and still have money left over." For a few examples of a more academic costs analysis see R. Sturm \& $\mathrm{K}$. Wells, "How Can Care for Depression Become More Cost-effective?" (1995) 273 JAMA 51; and H. Kattlove, "Benefits and Costs of Screening and Treatment for Early Breast Cancer" (1995) 273 JAMA 142.

See U.S. Congress, supra note 86 at 213 for a cost benefit analysis of cystic fibrosis screening. It was found that, in some scenarios, "sufficient savings accrue from avoided medical and caregiving costs to pay for costs associated with screening." See also Caulfield, supra note 108 at 221; and D. Morris, "Cost Containment and Reproductive Autonomy: Prenatal Genetic Screening and the American Health Security Act of $1993^{\prime \prime}$ (1994) 20 American Journal of Law and Medicine 295 at 302, who notes that the cost of caring "for a child with Down syndrome is estimated to be in excess of $\$ 500,000$. Compared with to these costs, the expense of undergoing prenatal screening is very small." Implications for Health and Social Policy (National Academy Press, 1993) at 1-20, made the following observation: 
We should remember that cost containment was one of the rationales for the first eugenic policies. During a eugenics exhibit in 1926 the American Eugenics Society had a display which flashed a light every time our society wasted a $\$ 100$ on people with "bad heredity."119 Will the new genetics and the current emphasis on health economics cause us to view a new generation of individuals as "costly"?

\section{Medical Legal Issues}

The introduction of new screening technologies may raise the expectations of the parent or parents to have a child free of a genetic disability. ${ }^{120}$ As a result, if a child is born with a disability which could have been tested for, either in utero or through carrier testing of the parents, the parents may feel compelled to sue the health care providers involved. ${ }^{121}$ These law suits, known as "wrongful birth" or "wrongful life" actions, ${ }^{122}$ have a number of implications for the present discussion. First, their mere existence may cause physicians to encourage the use of genetic services ${ }^{123}$ and to subtly recommend the termination of pregnancies which may result in the birth of a child with a disability. ${ }^{124}$

Second, because the success of these law suits depends on establishing that an injury has occurred which is worthy of damages, plaintiffs will need to demonstrate that a child is "disabled" and that "but for" the negligence of the health care provider they

The implications of such analysis that - if economic benefit were to be established testing should be encouraged, violates the principle of patient autonomy, with particularly grave consequences in testing for reproductive options. S. Jones, The Language of the Genes (London: Flamingo, 1993) at 18.

Such expectations may be fostered by the popular media. See e.g. S. Strauss, "All in the Family" The Globe and Mail (2 September 1995) at D8 where sub-title reads: "Thanks to a growing list of illnesses and deformities that can be identified by gene diagnosis, parents have a great chance of learning if they or their children harbour mutations." The article also notes that the number of tests done at the Hospital for Sick Children in Toronto "have increased from 1,070 in 1990 to 2,200 in 1994. Even higher totals would be expected if people could undergo any tests they wanted."

Freeman v. Sutter, [1996] 4 W.W.R. 748 (Man. C.A.); Arndt v. Smith (1995), 126 D.L.R. (4th) 705 (B.C.C.A.), leave to appeal to S.C.C. granted May 6, 1996 (S.C.C.); Cherry v. Borsman (1992), 94 D.L.R. (4th) 487 (B.C.C.A.); L. B. Andrews, "Torts and the Double Helix: Malpractice Liability for Failure to Wam of Genetic Risks" (1992) 29 Houston Law Review 149; K. Capen, "New Prenatal Screening Procedures Raise Spectre of More 'Wrongful-Birth' Claims" (1995) 152 CMAJ 734.

For a brief description of these actions see G. Robertson et al., "Legal Norms Relevant to the Practice of Human Genetics: A Background Paper" (1995) 3 Health Law Journal 187 at 201-03. See also K. Jankowski, "Wrongful Birth and Wrongful Life Actions Arising From Negligent Genetic Counselling: The Need for Legislation Supporting Reproductive Choicen (1989) 37 Prodham Urban Law Journal 27.

M. Renaud, "Canadian Physicians and Prenatal Diagnosis: Prudence and Ambivalence" in Research Volume 13, Royal Commission on New Reproductive Technologies (Ottawa: Royal Commission on New Reproductive Technologies, 1993) at 289, where it is reported that 62 percent of Alberta physicians surveyed thought that lawsuits would lead to more prenatal diagnosis than is medically required.

124 Operation" (1978) 4 Am. J. of Law \& Med. 131. 
would have had a "normal" child. ${ }^{125}$ What effect will this litigation have on our conception of children with disabilities?

\section{E. GUARDING AGAINST A NEW EUGENICS}

If we accept that a "new eugenics," manifested through individuals utilizing genetic services, has the potential to implicitly perpetuate and intensify societal prejudices and intolerance, how do we guard against it?

First, Canadians will need to decide to what degree individual choice should be circumscribed. In some areas there is already an emerging consensus (e.g. restricting sex selection, prenatal testing for superficial traits, etc.). ${ }^{126}$ However, these policies will need to be implemented in the current climate of patient empowerment. While this emphasis on patient choice is also a laudable trend in health care, it may, as demonstrated by Wertz's survey, complicate the process of genetic regulation. A clear and explicit genetic policy is essential.

Second, once we determine which services are to be available, we should ensure that decisions about health care, and the use of genetic services in particular, remain in the exclusive domain of the individual. ${ }^{127}$ Canadian case law, health care legisiation and health policy have continued to emphasize the importance of self determination in the realm of health care decisions. As tragically emphasized by the Muir case, any restriction of this individual right must occur in the rarest of circumstances - if ever. ${ }^{128}$

This is particularly so given the lack of success that plaintiffs have had in receiving damages for the birth of a "normal healthy" child. See e.g. Udale v. Bloomsbury Health Authority (1983), 1 W.L.R. 1098 (Q.B.); Doirin v. Orr (1978) 86 D.L.R. (3d) 719 (Ont. H.C.); and Cataford v. Moreau (1978), 114 D.L.R. 585 at 598, where the court states, "The Court is hesitant to convince itself that the parents are able in this way to cash in on their healthy child." See Testart, supra note 95 at 310-11 for a critique of various regulation mechanisms.

This idea has been embraced by a number of commentators. For example, Institute of Medicine, Assessing Genetic Risks: Implications for Health and Social Policy (Washington: National Academy Press, 1993) at 2-34 recommends as follows:

Autonomous decision making should be the goal in prenatal diagnosis and the committee recommends that health professional, society and the state be neutral on the outcome of individual reproductive choices.

Ledley, supra note 85 at 164 , has taken this concept further by arguing that if "genetic applications focus resolutely on preserving or extending individual liberties with the assent of the individuals concerned, then eugenic abuse is impossible." See also D. Heyd, "Prenatal Diagnosis: Whose Right?" (1995) 21 Joumal of Medical Ethics 292.

See Robertson, supra note 92 at 224:

[T] he new genetics cannot escape our strong normative commitment to procreative liberty.

Because genetic knowledge is relevant to the reproductive choices of many persons, it should be available to the widest extent possible. By the same token, it should also remain a matter of personal choice. Individuals, not government, should decide how to use genetic knowledge in reproduction.

It should be noted that obtaining consent in the area of genetics involves numerous unique problems. See e.g. Caulfield, supra note 108 at 222-28; and A. Goldworth, "Informed Consent in the Human Genome Enterprise" (1995) 4 Cambridge Quarterly of Healthcare Ethics 296. 
Third, we must endeavour to promote a continued belief in genetic equality, ${ }^{129}$ tolerance, a broad social view of normalcy ${ }^{130}$ and respect for individuals' health care decisions - be they reproductive choices or otherwise. To a large degree this is the most important safeguard as it informs and empowers the first two. Establishing this safeguard, particularly in the context of genetics, will be particularly difficult. We can not stop, and nor should we try, the flow of information which is being provided by the current genetic revolution. However, as many commentators have highlighted, this information has the potential to change the very way we view ourselves and those around us. As a result, some fear a "geneticization" of human diversity and disability which will result in a more restricted view of normalcy and an expanded view of disease. $^{131}$

Being aware of the relevant factors which may adversely impact social conceptions, such as commercial interests and cost containment, will, at least, sensitize us to potential pitfalls.

\section{CONCLUSION}

Fears about a "new eugenics," while justified, should not be allowed to result in a wholesale backlash against genetic research or the clinical application of genetic technology. A balanced and informed analysis is essential. The expanding genetic knowledge will undoubtedly provide numerous worthwhile scientific and medical breakthroughs. ${ }^{132}$ However, as argued by Clarke, we should "not allow the true justification of [genetic services] - the prevention of suffering, when this is sought by the families concerned - to be obscured" by other societal goals. ${ }^{133}$

For Keller, supra note 83 at 299 , it is the definition of normalcy, and who has the "authority for prescribing the meaning of "normal'" which is of critical importance. She concludes:

It is of course true that, in 1990, we have no Nazi conspiracy to fear. All we have to fear today is our own complacency that there are some "right hands" in which to invest this responsibility - above all, the responsibility for arbitrating normality.

See Burstyn, supra note 94 at 16; and Renaud, supra note 123 at 298, where it is reported that almost half the Canadian physicians surveyed thought that the introduction of prenatal genetic services will make disorders out of conditions which were once considered "normal" and will increase intolerance toward those with genetic anomalies. Of course, all are not so optimistic about the potential for this "genetic revolution." See e.g. R. Hubbard \& E. Ward, Exploding the Gene Myth (Boston: Beacon Press, 1993).

A. Clarke, "Genetics, Ethics and Audit" (1990) 335 Lancet 1145 at 1145. 